\title{
Wolica - uparta wieś na obrzeżach Warszawy
}

\author{
Wolica - a Stubborn Village \\ on the Outskirts of Warsaw
}

\section{Wstęp}

Według Encyklopedii staropolskiej Zygmunta Glogera, słowo „wolica” wywodzi się od rzeczownika „wola”, który jeszcze w XIX w. oznaczał wolność. O jaką wolność może chodzić? Oczywiście ekonomiczną. Z. Gloger pisze: „ziemię pustą, oddaną osadnikom z uwolnieniem ich na pewną liczbę lat od wszelkich służb, powinności i czynszów dla dziedzica, nazywano wolą. Od nazwy dóbr, w których wola została założoną, otrzymała właściwą swą nazwę w formie przymiotnikowej. Wolice i wólki [...] zaczęły powstawać w XIII w., ale najwięcej założono ich w XIV w."

Wolica to również nazwa dawnej wsi położonej na „skarpie warszawskiej”2. Obecnie znajduje się na terenie dwóch dzielnic - Ursynowa i Wilanowa. Po co o niej pisać? W końcu próżno by szukać jej w monografiach dotyczących historii Warszawy. Co więcej, wieś ta pojawia się w niewielu opracowaniach na temat samego Ursynowa czy Wilanowa. Również większość współczesnych warszawian nie ma pojęcia o istnieniu tego miejsca. A ci, którzy od niedawna mieszkają na Wilanowie i Ursynowie, zapytani o to czy słyszeli o wsi Wolica, kręcą przecząco głowami³. Wyjątkowość tego miejsca zasadza się na pewnym paradoksie. Przez większość okresu jej istnienia Wolica nie wyróżniała się niczym spośród okolicznych osad i wsi. Wielokrotnie zmieniała właścicieli. Przez wieki była wymieniana

I Z. Gloger, Encyklopedia staropolska, Warszawa 1903, s. 463.

2 Zwyczajowa nazwa naturalnej skarpy wiślanej na terenie Warszawy.

3 Wynika to z moich badań terenowych, jak i prywatnych rozmów. 
po przecinku, chociażby w księgach parafialnych Świętej Katarzyny, pierwszej wolickiej parafii. Mimo że została włączona do Warszawy już w I95 r r. ${ }^{4}$, na mapach stolicy można ją znaleźć opisaną jako „wieś Wolica”. Właśnie dlatego, dopiero $\mathrm{w}$ XX w., zaczęła się wyróżniać tym, że nie poddała się wpływom kulturowym Warszawy.

Na terenie Wolicy prowadzę badania etnograficzne. Interesują mnie kwestie dotyczące przestrzeni i zmiany krajobrazu z wiejskiego na miejski. Zmiany te zachodzity i zachodzą bardzo powoli, co czyni Wolicę wyjątkowo wdzięcznym obiektem antropologicznej eksploracji. Podczas moich badań rozmawiam nie tylko z woliczanami, ale i mieszkańcami pobliskiego Ursynowa i Wilanowa, którzy odwiedzali i odwiedzają wieś na skarpie. Zbieram opowieści o dniu codziennym mieszkańców Wolicy, ale i o relacjach z sąsiadami, którzy mieszkali w blokach z wielkiej płyty. Dlatego też w niniejszym artykule mającym przybliżyć dzieje Wolicy sięgam nie tylko do źródeł zastanych, ale i do wywołanych, przytaczając fragmenty wywiadów etnograficznych, które przeprowadziłam podczas moich badań.

\section{Wolica. Rys historyczny}

Jak wspomina Marta Piber, „Wola Służewska zwana także krótko Wolicą, bądź też Wolą Brzyszkową, pojawia się w źródłach na początku lat 20. $\mathrm{XV}$ w. Powstanie jej można zatem datować w przybliżeniu na drugą połowę XIV w."' Od początku Wolica była wsią podległą parafii służewskiej, de facto najstarszej parafii w granicach dzisiejszej Warszawy.

Wikariusz kościoła w Służewie po raz pierwszy występuje w źródłach w I427 roku. Być może jednak pojawienie się tej funkcji w kościele służewskim należy datować na ostatnie dziesięciolecia XIV wieku, kiedy na terenie parafii przybyło kilka nowych osad, co spowodowało znaczny wzrost liczby parafian. Wszystkie wsie, z których dziesięcinę pobierał pleban, położone były w niewiększej odległości od kościoła niż $5-6 \mathrm{~km}$, oprócz Służewa były to Wolica Służewska, Wyczółki, Służewiec, Jemielino, Dzbarz, Korzkiewki, Raków i Okęcié.

4 Monitor Polski 195ı, nr 60, poz. 809, Zarządzenie nr 106 Prezesa Rady Ministrów z dnia 30 czerwca I95 I r. w sprawie szczegółowego przebiegu granicy miasta stołecznego Warszawy i powiatu warszawskiego.

5 M. Piber, Stużewśredniowieczny. Dzieje parafii i wsi Stużew w ziemi warszawskiej, Warszawa 200I, s. 2 I2.

6 M. Piber-Zbieranowska, Kościót i parafia stużewska w średniowieczu, [w:] Stużew i jego kościót, red. A. Sołtan-Lipska, Warszawa 2013, s. 24-25. 
Wieś Wolica do końca XVII w. należała do dóbr szlacheckich rodów Wierzbowów, Służewskich i Dąbrowskich. Następnie trafiła do dóbr wilanowskich króla Jana III Sobieskiego. W ich skład wchodziły trzy klucze: Wilanów, Zastów i Chojnów. Przyjmuje się, że Wolicę przyłączono do klucza wilanowskiego na przełomie lat 80 . i 90 . XVII w.7 Później, przez prawie sto lat (1799-I892) dobra wilanowskie należały do rodu Potockich'. W Diametrze Piaciu Mil ${ }^{9}$ Karola de Perthées z 1783 r. prócz Wolicy widać też inne wsie należące do klucza wilanowskiego. Rozkosz i Wolica leżą na skarpie wiślanej. Droga, która przecina wieś na północny wschód, to trasa do Wilanowa. Pokrywa się z dzisiejszą ul. Hlonda. Natomiast droga zaznaczona przerywanymi liniami, przy której leży Wolica, to tzw. gościniec, dzisiejsza ul. Nowoursynowska. Widać więc, że układ ważniejszych dróg pozostał ten sam. Pod koniec XIX w. właścicielami Wolicy byli Braniccy. Utworzyli oni na jej terenie folwark zwany Folwarkiem Wolica.

Przed drugą wojną światową tereny tego folwarku zostały przejęte przez państwo, natomiast po wojnie przekazano je warszawskiemu przedsiębiorstwu miejskiemu - Administracji Gospodarstw Rolnych i Leśnych (AGRiL). Następnie trafily do Państwowych Nieruchomości Ziemskich, które utworzyły na bazie folwarku Państwowe Gospodarstwo Rolne (PGR) Wolica. W 1957 r. właścicielem części gruntów stała się Szkoła Główna Gospodarstwa Wiejskiego w Warszawie (sGGW) ${ }^{\mathrm{ro}}$.

Na stronie internetowej Miasta Stołecznego Warszawy ${ }^{\mathrm{II}}$ znajduje się ciekawa ortofotomapa z nałożoną warstwą z planu Warszawy z 1939 r. Warto zwrócić uwagę na niezmieniony układ ulic Kokosowej, Nowoursynowskiej i Imbirowej.

\section{Zmiany przestrzeni w wiekach XX i XXI}

Jak wspomniałam, wieś Wolica została włączona do Warszawy w połowie XX w. Była jednak w granicach stolicy jedynie „na papierze”. Przez ponad trzydzieści lat krajobraz wsi nie ulegał zmianie. Pierwsze typowo miejskie budynki zaczęto wznosić w Wolicy dopiero na początku lat 90. XX w.

7 "Jeszcze przed rokiem 1684 do dóbr dołączony został Powsin, [...] a między I 684 i 1693 Zawady (od probostwa błońskiego) i części Powsina Wielkiego z Łazami, Lisami, Kempą i Kierszkiem (od Rusieckich i Ciołka) oraz części Wolicy (od Służewskiego) i Służewa”. P. Szpanowski, Warstwy krajobrazu klucza wilanowskiego, Warszawa 2015 , s. 37.

8 Tamże, s. 4I.

9 http://igrek.amzp.pl/11780719 [dostęp: I czerwca 2020].

Io http://wobiak.sggw.pl/wydzial/historia/ [dostęp: 29 maja 2020].

II http://mapa.um.warszawa.pl/mapaAppi/mapa?service=mapa_historyczna [dostęp: I czerwca 2020]. 
Osiedla budowano na dawnych polach i łąkach, dzięki czemu ocalała większość wiejskiej zabudowy. Woliccy gospodarze zaczęli rozbudowywać swoje domy dopiero pod koniec wieku. Dziś wprawne oko rozpozna dawną bryłę dwuizbowej chaty, która została powiększona o kolejne pomieszczenia, a następnie otynkowana.

Zmiany w przestrzeni Wolicy zachodziły bardzo powoli. Pani Katarzyna, moja informatorka, wychowywała się na Ursynowie. Mieszkała w bloku, a w pobliskiej wsi spędzała czas wolny. Chodziła tam z kolegami, koleżankami i rodziną. Tak wspomina krajobraz Wolicy:

To wyglądało... Pamiętam, że były kocie łby, jak się szło do Wolicy, gdzie jest teraz pizzeria, w nowym budynku. Była tam droga prowadząca do Wolicy. Tam po lewej stronie, no teraz są nowe, a w tamtym czasie to były chatki, ludzie mieszkali w takich starszych domach. Dużo było takich starych zabudowań. Chałupek. Później, jak się schodziło na dół tamtą skarpą, co droga prowadzi do Wilanowa. Teraz na tej skarpie stoją wypasione domy. A kiedyś to tam było tak... No tak... Jak w takiej dziurze. No tak, naprawdę, w takiej dużej dziurze. Te czworaki były tam. Tak pamiętam, jako po prostu taką opuszczoną, zapuszczoną wieś. [...] Taką starą, jakby to powiedzieć, czas się zatrzymał. Jakby wejść do dziewiętnastego wieku. Pamiętam takie wrażenie, że w tamtych czasach to było takie naprawdę. Coś było starego, no prawdziwa wieśr ${ }^{\prime 2}$.

Wiejski charakter Wolicy zachował się również w języku. Wielu moich informatorów nadal mówi „idę do Wolicy” czy „jestem w Wolicy”. Dawna wieś istnieje jako odrębny byt wymykający się podziałom administracyjnym. W języku moich rozmówców zachował się dawny podział na Wolicę i Ursynów, mimo że już od 1994 r. część dawnej wsi należy właśnie do Ursynowa. „Tamta strona ulicy jeździ na głosowanie do Ursynowa, a my do Wilanowa”'

W 2017 r. ruszyła budowa Południowej Obwodnicy Warszawy, której trasa przecina Wolicę. Z tego powodu wyburzono stajnię i czworaki należące do SGGW, które powstały w latach 50. XX w. Budowa obwodnicy to pierwsza inwestycja tak głęboko ingerująca w przestrzeń wsi. Aby pokazać, jak bardzo zmieniła się przestrzeń Wolicy w ciągu ostatnich 70 lat, wybrałam trzy typowe dla tej wsi punkty (A, B i C). Można je potraktować jako metafory palimpsestu, przez który rozumiem, za Anną Zalewską, „proces nakładania się kolejnych działań, których pozostałości zostają w jego toku tylko częściowo

I2 Wywiad z Panią Katarzyną, mieszkanką Ursynowa, przeprowadzony is V 2020 r.; archiwum autorki.

I3 Wywiad z Panią Gabrielą, mieszkanką Wolicy, przeprowadzony 23 XI 2019 r.; archiwum autorki. 
zatarte bądź zmienione" ${ }^{14}$. Obserwując zmianę charakteru tych miejsc, można zauważyć, że urbanizacja postępowała wyjątkowo wolno jak na realia stolicy. A niektóre elementy wiejskiego krajobrazu zachowały się do dziś.

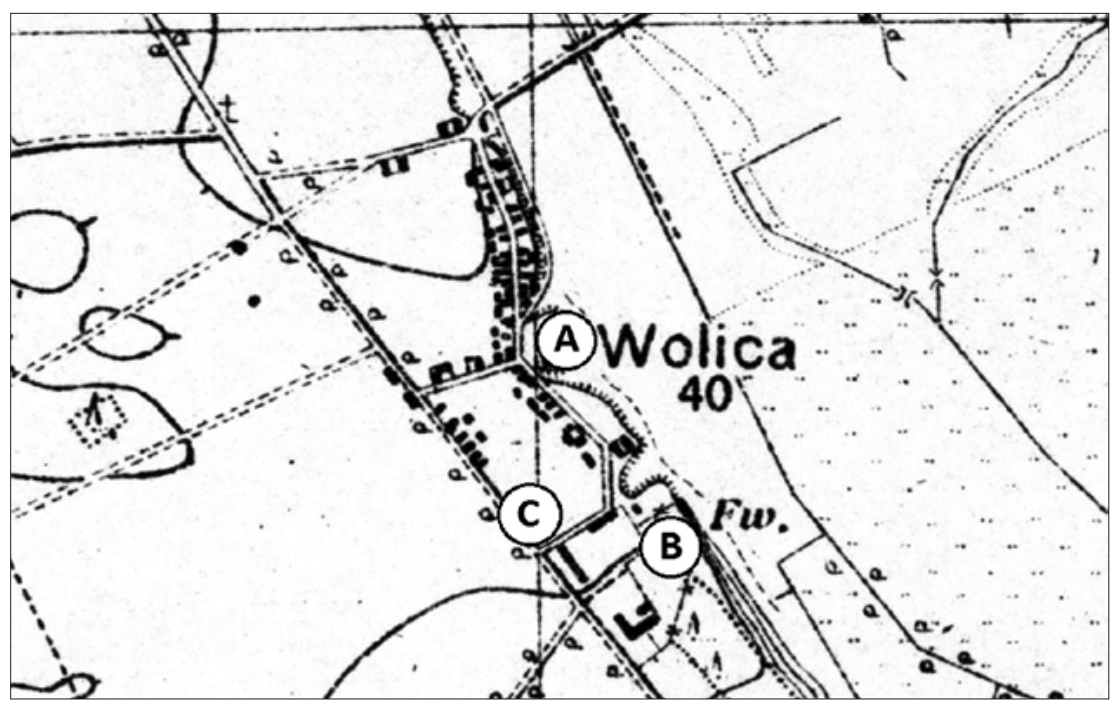

IL. 1 Plan wsi Wolica, połowa $\mathrm{xx}$ wieku

(http://igrek.amzp.pl/11777162 - dostęp: 2 czerwca 2020).

Uwaga: Zaznaczone przeze mnie miejsca na mapie z poł. xxw. to: A - górka, B - folwark i PGR, C - pętla autobusu linii ı04, kuźnia i warsztat mechanika.

\section{A. Górka}

Tak zwana „górka” na skarpie była centralnym punktem wsi Wolica. Jeszcze na początku XX w. stała tam szkoła powszechna. Tak wspomina ją moja informatorka, Pani Gabriela, której rodzina mieszka w Wolicy od wielu pokoleń:

A mieszkali prawie wszyscy, bo tu to nigdy nie było kościelne, bo to było zawsze szkolne tak zwane. I tu pierwsza, jaka była na Wolicy szkoła, to mi mama opowiadała, to właśnie była ta czteroklasowa szkoła, tu, pobudowana na tej górce. I dzieciaki z tych, od pierwszej do czwartej klasy. Chodziło bractwo. [...] Tu dzieciaki chodziły, a później tu się bawiły. Później, jak się ta szkoła rozsypała, drugiej nie pobudowali, to był piękny teren zabawy dla wszystkich dzieci. Łącznie i ja, i wszyscy, i córka, i wnuczki się bawiliśmy ${ }^{15}$.

\footnotetext{
I4 A. Zalewska, Palimpsest, [w:] Modi memorandi. Leksykon kultury pamięci, red. M. Saryusz-Wolska, R. Traba, Warszawa 2014, s. 318.

Is Wywiad z Panią Gabrielą.
} 
Według relacji moich rozmówców, z górki rozpościerał się widok na pola uprawne i działki robotnicze. Pola kukurydzy i rzepaku ciągnęły się aż po horyzont. Ze skarpy można było dostrzec nawet pałac w Wilanowie. Dziś jest to niemożliwe, widok zasłania Miasteczko Wilanów, nowe osiedle wybudowane na terenie dawnych pól PGR-u. Na zielonym placu stały - i stoją do dziś - krzyż i studnia, przy których wypasano krowy. Górka aż do początku XXI w. była też miejscem zabaw dzieci i młodzieży z Wolicy i Ursynowa. Pani Katarzyna, wspomniana wcześniej mieszkanka Ursynowa, tak wspomina wyprawy do pobliskiej wsi:

Czasami braliśmy koc. Była woda ze studni, nie trzeba było picia brać. I się tak szło z marszu. Jak było ciepło, pamiętam, non stop się latało. Pamiętam zabawy w warzywniak. Zbieranie babki jako monety, środek pieniężny, liście babki. No i tak pamiętam rwanie kwiatów polnych, bo tam łąki były. Dla dziewczyn zawsze coś się znalazło. A chłopaki to tam cuda robili. Znam takich, co lubili biegać i stogi podpalać. [...] Na rowerach też dużo ludzi pamiętam. Rowerami się dużo jeździło po okolicy ${ }^{16}$.

Jak wspomina Pani Gabriela, która mieszka w Wolicy od dziecka, górka żyła także zimą. „Przecież była studnia, ta co jest, no to panowie stawali, ciągnęli wodę i wylewali, więc było lodowisko, już ja miałam lodowisko, po kolei rodzice się zbierali. I moje wnuczki też, wszystko! Było lodowisko i jeździli, nie musieli nigdzie chodzić” ${ }^{17}$. Na górce organizowano też potańcówki i obchodzono sylwestra. Miejsce to tętniło życiem. Dowodem na to, że bardzo długo zachowywało swój wiejski charakter, może być scena z filmu Pitkarski poker w reżyserii Janusza Zaorskiego. Wolica „zagrała” tam Podlasie. Warto zaznaczyć, że film powstał w 1989 r. Nawet u progu XXI w. Wolica przypominała bardziej wieś niż miasto (droga gruntowa, łąki, studnia, mała architektura sakralna - przydrożny krzyż). Dwa ostatnie elementy pejzażu Wolicy egzystują w dzisiejszym krajobrazie górki, lecz radykalnie zmieniło się tło. Górka jako sielskie miejsce wypoczynku i zabaw przetrwała do $2000 \mathrm{r}$. Wtedy zaczęto wznosić kościół na terenie pierwszej wolickiej parafii pod wezwaniem bł. Edmunda Bojanowskiego. W ciągu ostatnich kilkunastu lat krajobraz górki zmienił się bezpowrotnie. Po dawnym wiejskim miejscu spotkań i zabaw zostały tylko krzyż i studnia.

I6 Wywiad z Panią Katarzyną.

I7 Wywiad z Panią Gabrielą. 


\section{B. Folwark Wolica, PGR Wilanów, wylot Południowej Obwodnicy Warszawy}

Na południowym krańcu Wolicy znajdował się folwark. Jak wspominałam, jeszcze przed II wojną światową jego właścicielami byli Braniccy. Jednym z bardziej charakterystycznych budynków pamiętających te czasy był olbrzymi czworak, największy w całej wsi. Jeszcze na początku XXI w. mieszkali w nim potomkowie służby Branickich ${ }^{18}$. Budynek nazywano chatą turecką. Legenda głosi, że chata ta pochodzi z XVII w. Jej pierwszymi mieszkańcami mieli być janczarzy sprowadzeni tu przez króla Jana III Sobieskiego ${ }^{19}$. W materiałach źródłowych próżno by szukać potwierdzenia tej tezy. Pewne jest to, że chata była jedną z najstarszych na terenie dzisiejszego Ursynowa. Spłonęła w $201 \mathrm{r}$ r. Po drugiej wojnie światowej na bazie folwarku powstał PGR Wolica. W 1956 r. właścicielem gruntów została SGGW, która urządziła swoje pole doświadczalne. Tak wspomina je Pani Beata:

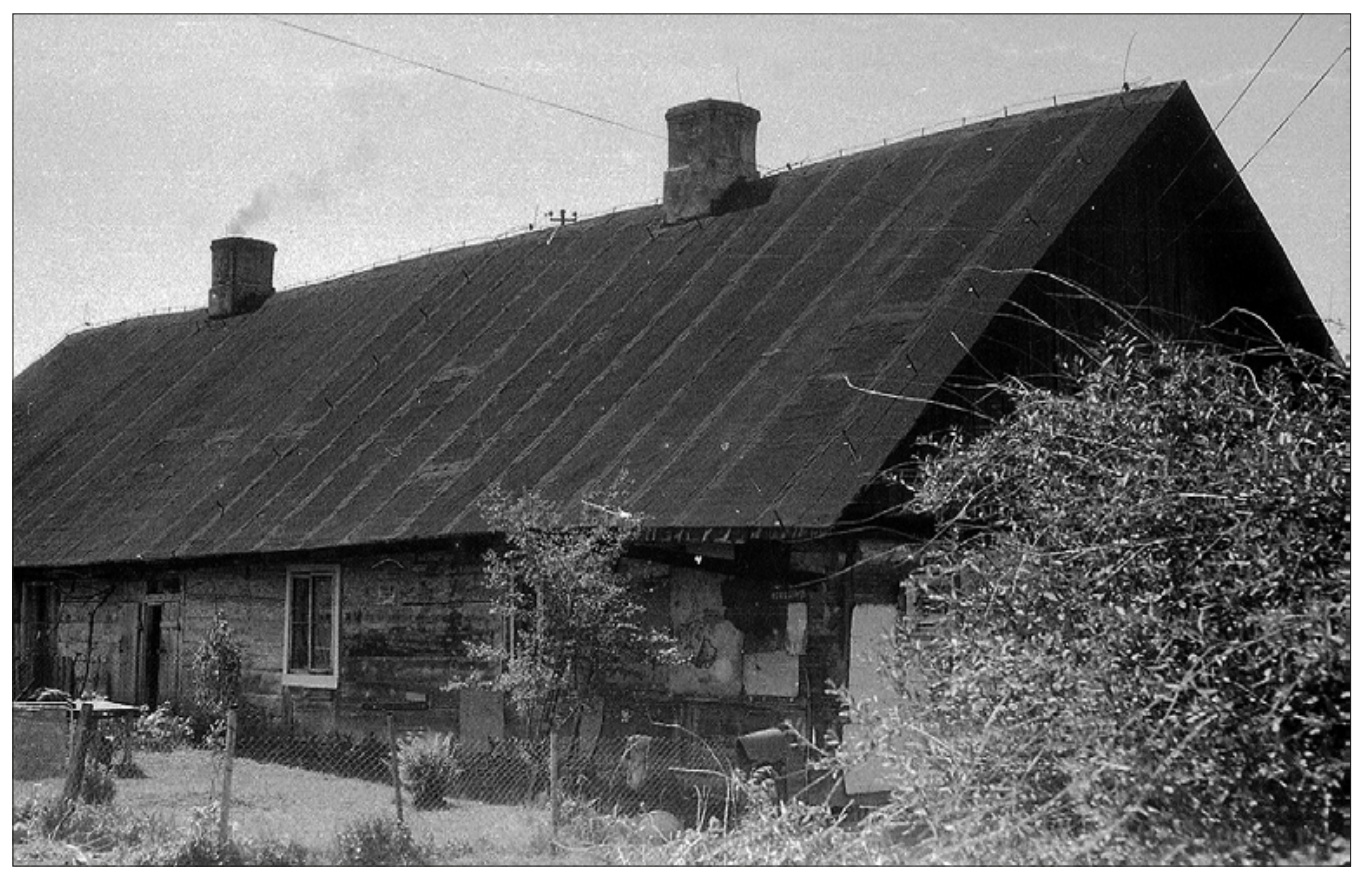

Fот. 1 Chata turecka w latach 90. XX w. (Archiwum Stefana Gardawskiego, fot. S. Gardawski)

I8 Tamże.

I9 „Chata stała na skraju skarpy, przy Kokosowej. Wielka drewniana chałupa. Największa ze wsi Wolica. Legenda głosi, że postawili ją Turcy wzięci do niewoli pod koniec siedemnastego wieku”. M. Mazur, Czterdziestolatek. Historie z Ursynowa, Warszawa 2017, s. 138. 
Była sprowadzana dopiero czarna folia, w Polsce nikt jeszcze nie słyszał o tym. Więc oni mieli tym wyłożone poletka, bo na dole, tam gdzie w tej chwili będzie autostrada, były wielkie łąki, plus były poletka doświadczalne. Oprócz tego, że był jeszcze rzepak, że były... Były... Były ogromne stogi siana, gdzie się bawiliśmy... To właśnie były te poletka i te poletka już były oczywiście ogrodzone. I tam na przykład po raz pierwszy widziałam czarną folię. I było śmiesznie, jak to wozili tymi traktorami z przyczepą, a dzieciaki wszystkie biegły i zbierały, co spadło, no bo właśnie spadały melony i arbuzy ${ }^{20}$.

Pracowników PGR-u zakwaterowano w specjalnie dla nich wybudowanych czworakach. Zostały zburzone dopiero w 2018 r. Prawdopodobnie stałyby tam do dziś, gdyby nie budowa Południowej Obwodnicy Warszawy. Jej trasa będzie przebiegać przez środek dawnych zabudowań PGR-u.

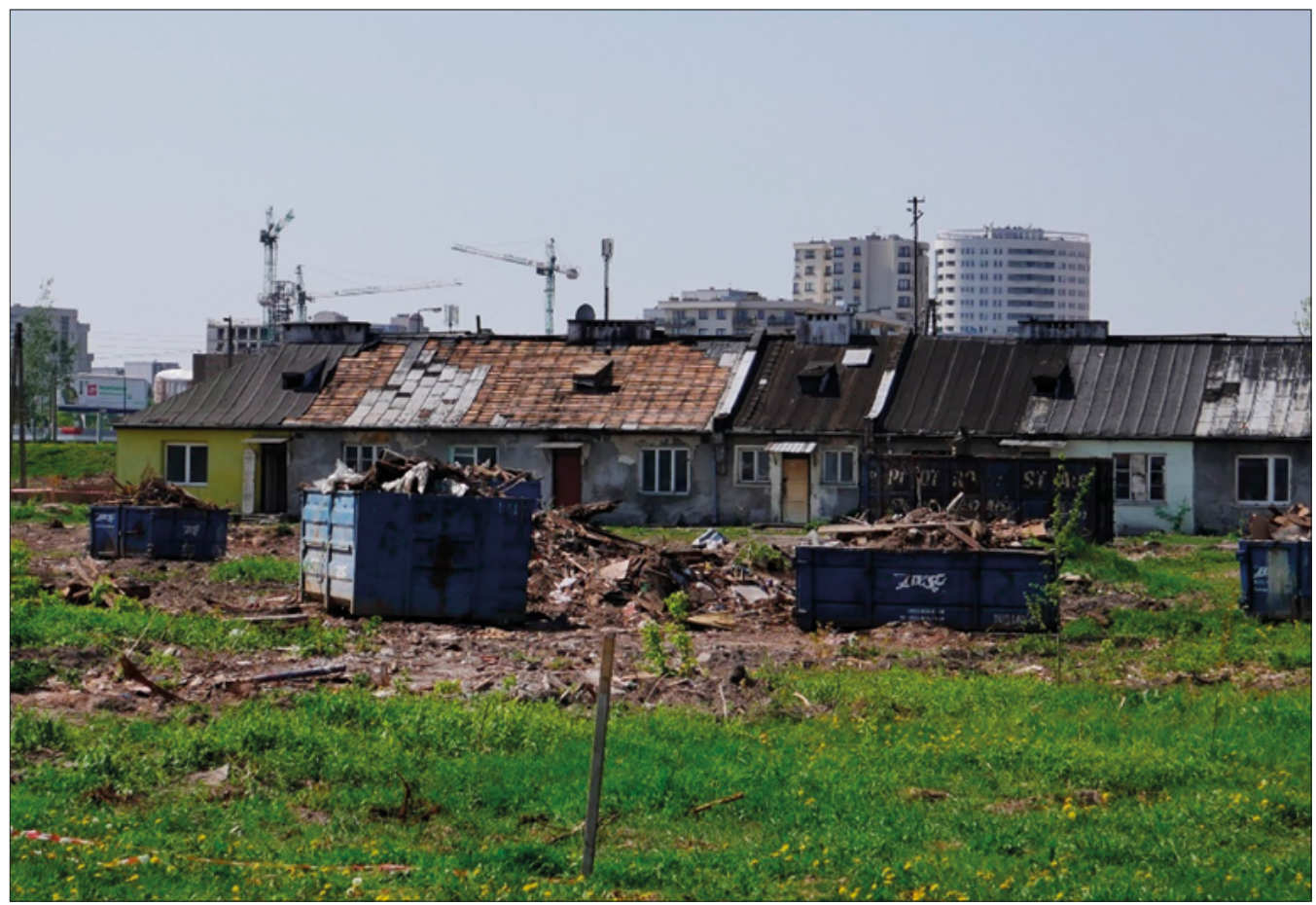

FOT. 2 Czworak pracowników PGR-u (fot. J. Kunikowska)

Uwaga: Zdjęcie z wiosny 2018 r. Budynek został zburzony kilka dni później.

Na pierwszym planie (wbity pal) stała słynna chata turecka.

20 Wywiad z Panią Beatą, mieszkanką Wolicy, przeprowadzony 23 XI 2019 r.; archiwum autorki. 


\section{Pętla autobusu 104, kuźnia, warsztat mechanika}

W 1948 r. uruchomiono linię autobusową numer 104. Miała łączyć Warszawę z rolniczymi terenami Ursynowa. Linia ta była pierwszą, która kursowała na południe ${ }^{21}$. Na początku istnienia linii, tuż po wojnie, jako autobusy kursowały samochody ciężarowe. Pani Gabriela wspomina: „To były ciężarowe samochody, tylko schodki były i po tych schodkach się wchodziło. Stonka! O! Do stonki. A tu było tak fajnie, że jak się leciało Imbirową, a już facet jechał, tylko rękę się podniosło, to stawał, wsiadało się i jechało dalej”'22.

Autobus Io 4 był przez dziesięciolecia jedynym łącznikiem Wolicy z miastem. Do lat 80 . XX w., kiedy powstały pierwsze bloki osiedla Natolin, na "głębokie południe” Warszawy można było dojechać wyłącznie linią I04. Pętla autobusowa o nazwie „Wolica” mieściła się przy ul. Nowoursynowskiej, która jeszcze pod koniec ubiegłego wieku była pokryta kocimi łbami. Tuż obok pętli znajdowała się kuźnia, w której pracował kowal. Jeszcze do niedawna podkuwano tam konie ciągnące wolickie furmanki. Budynek przetrwał. Obecnie mieści się w nim zakład mechanika samochodowego.

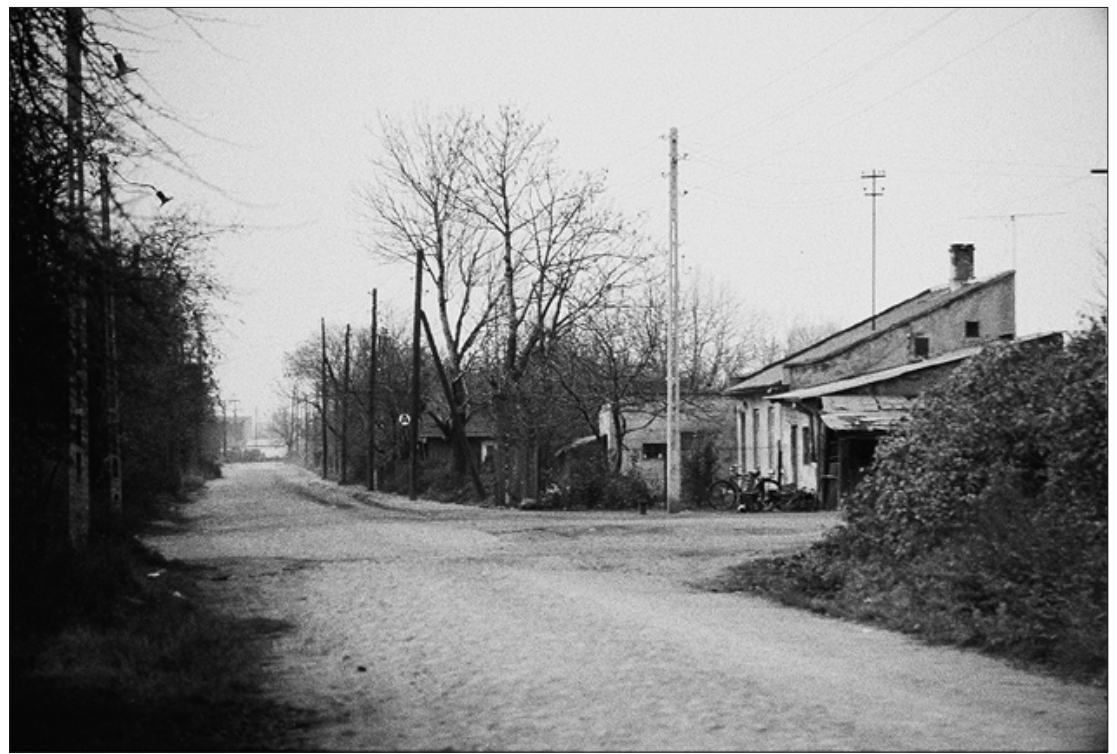

FOT. 3 Pętla autobusu linii io 4 (fot. L. Pytko)

Uwaga: Budynek po prawej stronie to kuźnia. Warto zwrócić uwagę na kocie łby, którymi wyłożona była ul. Nowoursynowska.

21 http://www.trasbus.com/komı948.htm [dostęp: 25 maja 2020].

22 Wywiad z Panią Gabrielą. 


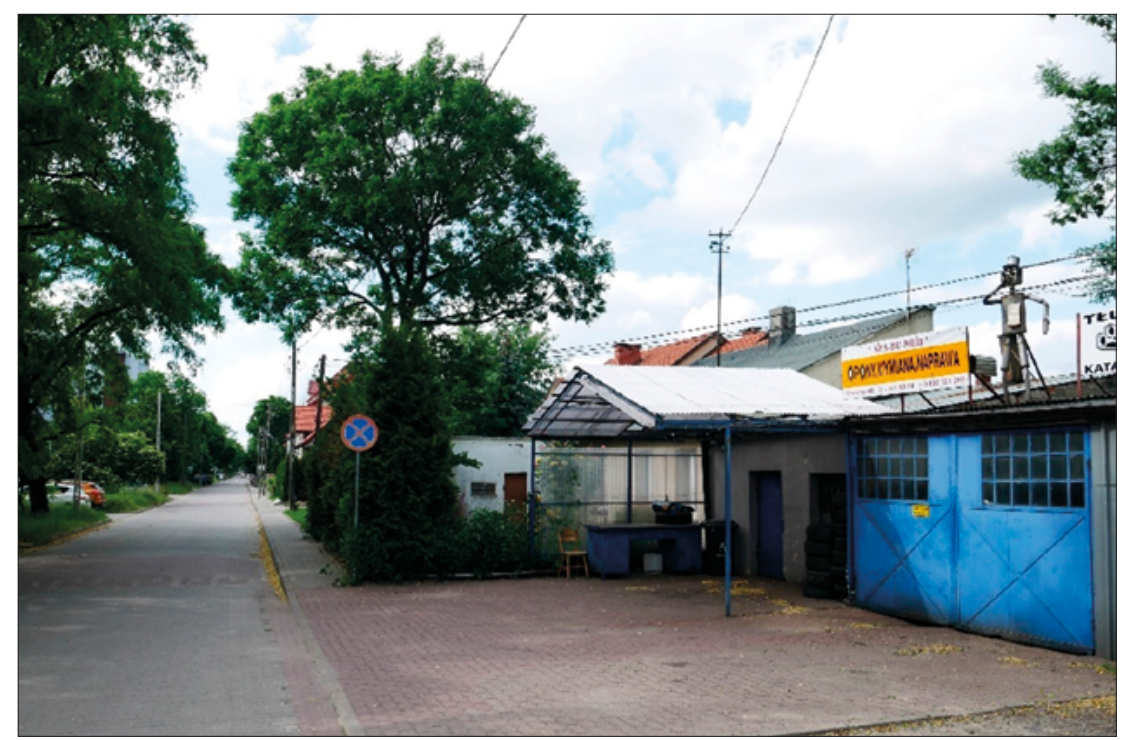

FOT. 4 Dawna kuźnia, obecnie warsztat mechanika (fot. J. Kunikowska)

Uwaga: W miejscu znaku drogowego był kiedyś przystanek linii 1o4.

\section{Podsumowanie}

Interesuje mnie dynamika miejsc charakterystycznych dla dawnej Wolicy. Miejsc, które zanikają, ale i żyją, zmieniwszy swoje znaczenie. Opisane przeze mnie trzy palimpsesty to zaledwie trzy z wielu reliktów dawnej wsi. Wolickich krzyżów, takich jak ten stojący przy kościele, jest więcej. Jeden z nich stał na rozstaju dróg i wyznaczał granicę między Wolicą a sąsiednią wsią. A dziś? Stracił swoją pierwotną funkcję. Nadal stoi na rozstaju, ale dwóch osiedlowych ulic. Wokół wyrosły wysokie bloki, a droga, przy której stoi, dawniej piaszczysta, dziś jest brukowana. Dawna wieś stale się zmienia. Czasami są to drobne zmiany, które trudno zauważyć, nie będąc w danym miejscu codziennie. Bywa też, że po wyburzeniu jednego budynku trudno odnaleźć się w przestrzeni. Dlatego badając miasto, należy przyglądać się możliwie wielu, nawet tym pozornie nieistotnym elementom. Według antropologa i badacza miasta Tima Ingolda, to ścieżka, a nie miejsce jest podstawowym warunkiem istnienia ${ }^{23}$. Dlatego badając miejsca takie jak dawna wieś Wolica, które mogą pochwalić się długą historią, należałoby przyjrzeć się trwaniu pewnych elementów krajobrazu, przeanalizować to,

23 T. Ingold, Splatać otwarty świat. Architektura, antropologia, design, przeł. E. Klekot, D. Wąsik, Kraków 2018. 
jak zmieniały się w czasie. Palimpsesty przeze mnie przedstawione w zarysie, choć pozornie nieważne i nieatrakcyjne, stanowią źródło wiedzy o przeszłości i dynamikach, które rządziły dawną wsią.

Wolicę ominęly wielkie wydarzenia historyczne, które uczyniły stolicę sławną, ale zarazem stały się jej tragedią. W trakcie drugiej wojny światowej mieszkańców lewobrzeżnej Warszawy wysiedlono. Natomiast w Wolicy, oddalonej zaledwie o ro km od obecnego centrum Warszawy, do dziś mieszkają potomkowie dwóch rodzin - Sakowskich i Chodzeniów, które żyją tu od kilkuset lat. W Wolicy zachowały się też domy mieszkalne pamiętające początek ubiegłego stulecia. Niewiele zmieniła się też sama przestrzeń. Ocalał dawny układ ulic, jak i charakterystyczne elementy, takie jak przydrożne krzyże. Ocalały także drzewa, chociażby prawie stuletni jesion przy pętli autobusu I04.

Mogłoby się zdawać, że skoro wieś tyle przetrwała, będzie dalej istnieć. Od 2017 r. zagraża jej jednak budowana Południowa Obwodnica Warszawy. W ciągu ostatnich trzech lat przestrzeń Wolicy zaczęła się gwałtownie zmieniać. Zniknęły drewniane i murowane budynki pracowników PGR-u, zniknęła też stajnia SGGW. Na miejscu dawnej zabudowy folwarcznej pojawił się tunel obwodnicy. Przez wiele lat Wolica pozostawała wolna od wpływów miasta. Dlatego przetrwała. Pytanie: Czy i tym razem jej się uda?

\section{Bibliografia}

\section{Źródła archiwalne}

Archiwum autorki

Archiwum rodziny Pytko

Archiwum Stefana Gardawskiego

\section{Źródła drukowane}

Monitor Polski 195I

\section{Opracowania}

Gloger Z., Encyklopedia staropolska, Warszawa 1903.

Ingold T., Splatać otwarty świat. Architektura, antropologia, design, przeł. E. Klekot, D. Wąsik, Kraków 2018.

Mazur M., Czterdziestolatek. Historie z Ursynowa, Warszawa 2017.

Piber M., Stużew średniowieczny. Dzieje parafii i wsi Stużew w ziemi warszawskiej, Warszawa 2001 .

Piber-Zbieranowska M., Kościót i parafia stużewska w średniowieczu, [w:] Stużew i jego kościót, red. A. Sołtan-Lipska, Warszawa 2013.

Szpanowski P., Warstwy krajobrazu klucza wilanowskiego, Warszawa 2015.

Zalewska A., Palimpsest, [w:] Modi memorandi. Leksykon kultury pamięci, red. M. Saryusz-Wolska, R. Traba, Warszawa 2014. 


\section{Filmy}

Pitkarski poker, reż. Janusz Zaorski, 1989.

\section{Strony internetowe}

MAPA Warszawy UM, http://mapa.um.warszawa.pl/mapaAppi/mapa?service=mapa_historyczna MAPSTER, http://igrek.amzp.pl/

Trasbus. Historia Warszawskiej Komunikacji Miejskiej, http://www.trasbus.com/

Wydział Ogrodnictwa i Biotechnologii Szkoły Głównej Gospodarstwa Wiejskiego, http:// wobiak.sggw.pl/

Streszczenie: Celem artykułu jest przybliżenie historii dawnej wsi Wolica, leżącej na skarpie warszawskiej. Pierwsze zapiski o wsi pochodzą już z XVw. Wioska należała do wielu rodów magnackich - Potockich, Branickich, a nawet do króla Jana III Sobieskiego. Przez ponad pół tysiąca lat niczym się nie wyróżniała. Interesujące jest to, że zaczęła wyróżniać się dopiero w XX w., kiedy znalazła się w granicach Warszawy. Długo nie poddawała się postępującej urbanizacji stolicy. Autorka, studentka etnologii, skupia się na przemianach przestrzeni Wolicy. By udowodnić swoją tezę, cytuje fragmenty wywiadów z mieszkańcami okolicy. Wywiady zostały zarejestrowane na terenie Wolicy podczas badań etnograficznych, które autorka nadal prowadzi.

Słowa klucze: Wolica, Warszawa, urbanizacja, etnografia, lokalność

Summary: The purpose of this article is to present the history of the former village of Wolica, located at the Warsaw Escarpment. Wolica was firstly mentioned in isth century. The village was the property of many noble families like the Potocki, the Branicki and even to King Jan III Sobieski. For over 500 years Wolica did not stand out at all. Surprisingly, it began to make its mark in the 20 th century, when it was incorporated to the capital. Despite the progressing urbanisation of Warsaw, it retained its rural character. The author, an ethnology student, focuses on the spatial changes in Wolica. To prove her point, she cites some of interviews with the locals, which were conducted during her field research in Wolica, that continues.

Keywords: Wolica, Warsaw, urbanisation, ethnography, indigenousness 